\title{
Maternal Employment in Post-socialist Countries: Understanding the Implications of
}

\section{Childcare Policies}

\section{Jana Javornik}

\section{Introduction}

Post-socialist countries, especially those from the EU-2004 enlargement, have been distinguished by high employment rates of women in full-time jobs since the late 1950s. In the Czech Republic, Hungary, Poland, Slovakia and Slovenia from Central Europe, and Estonia, Latvia and Lithuania from the Baltic States, these ranged between 85 and 90 per cent, with practically no cross-country variation and narrow gender gaps in the late 1980s, just before the severe labour market disruptions in the 1990s (for example United Nations Children's Fund UNICEF, 1999).

Scholarship on female employment largely relates these trends to their 'exceptional' socialist history and legacy, maintaining that the socialist states had designed generous childcare policies aimed at supporting female employment (for example Einhorn, 1993; van der Lippe and Van Dijk, 2001: 5; Pascall and Lewis, 2004: 375-7; Pascall and Kwak, 2005: 29). Pascall and Manning argue that these endorsed and legitimized social norms, and affirmed the place of women in society as well as secured their legislative protection in the labour markets (2000: 248).

Focusing on this early transformative period, literature on the gendered welfare state often conveys a sense of fundamental shift from the socialist past, arguing that 'the winds of change' evoked 'a renaissance' of traditional gender roles and familialism (for example Pascall and Lewis, 2004: 375-7; Pascall and Kwak, 2005: 29; Funk, 1993: 2; Einhorn, 1993; 
Gal and Kligman, 2000; for an overview see Javornik, 2010 and Motiejūnaite, 2008: 83). These authors argued that, lacking public subsidies and political support, public childcare would plummet; childcare would be re-familialized, and women driven off the labour markets.

On the other hand, the 'anti-feminist sentiment' thesis argues that, given the opportunity, women would opt out of jobs to stay home with their children (for example Einhorn, 1993; Gal and Kligman, 2000; Pascall and Kwak, 2005). This scholarship argues that socialist politics produced cheap labour and overburdened women (for example Gal and Kligman, 2000) and that conditions of work, low wages, and the magnitude of public-private demands evoked a sense of victimization and a perennial guilt in women, who felt that they were never able to do 'enough of anything, especially the mothering' (echoed as 'female brave victim' in Gal and Kligman, 2000: 53). 'Forced' by the authoritarian socialist governments, women would, thus, 'choose' to leave the labour market when possible (for an overview see Motiejūnaite, 2008: 20-24; Saxonberg and Szelewa, 2007: 354-5). Therefore, a new awakening - compelling women to substitute one type of life for another - would not be perceived as the 'redomestification' of women. Taken together, this literature anticipated that women would return in droves to domestic lives; only a few had suggested that paid labour might also be a source of self-realization and autonomy - and, as such, a benefit worth defending (for example Einhorn, 1993: 114; Motiejūnaitè, 2008: 86).

This strand of transition literature significantly informed the welfare state regime theory, which overwhelmingly introduced a single 'post-socialist', 'post-communist' or 'Eastern European' familialistic cluster (for example Rostgaard, 2004; Hantrais, 2004; Saraceno and Keck, 2008: 63). This is problematic for three reasons. First, the empirical evidence suggests otherwise. Although the decline in female employment in the early years of the 1990s was 
significant, in retrospect, this was a blip of a readjustment. Namely, between 2000 and 2008, the employment rates for women in full-time jobs were, on average, again at about 80 per cent and over, with practically no cross-country variation, and with fairly narrow gender gaps (UNICEF, 1999; EC, 2008; Eurostat, 2008). Thus, much of this writing was premature, reflecting rather the period of 'exceptional' politics (King, 2002: 5), when countries were building up the conditions to 'go back to normalcy' (Kovács, 2002: 176). Second, conclusions are largely drawn based on only a few countries, those that have received more scholarly attention, that is, Hungary, the Czech Republic and Poland. This opens the issue of 'representation', more so as these notably represent the familialistic spectrum (for example Fodor et al., 2002; Szelewa and Polakowski, 2008; Javornik, 2010; Thévenon, 2011). Third, it is often neglected that within the broad category of 'female employment' something else is going on. Namely, the employment rates for women aged 25-49 years who had pre-school children and those who did not contrast sharply; between 2000 and 2008 the employment rates for women with pre-school children ranged from 50 per cent in Hungary, Slovakia and the Czech Republic, to about 90 per cent in Slovenia. Such variation seems at odds with the re-traditionalization thesis suggesting that mothers' employment would be (equally) low in these countries.

This variation in the employment patterns provided a source of inspiration for my analysis, which explores the employment-policy nexus during the period 2000-2009. Considerable bodies of research demonstrate that parental leave and childcare services (hereafter referred to as policies on childcare) have the highest explanatory power for cross-country variation in female employment (for example Ruhm, 1998; Rubery et al., 1998: 223-234; Pettit and Hook, 2005; Uunk et al., 2005; Eliason et al., 2008; Misra et al., 2010; for an overview see Javornik, 2010). Moreover, the feminist critique of the welfare-state regimes maintains that the normative assumptions (hereafter referred to as policy logics) about the social organization of 
childcare (state-family-market nexus) and gender roles most clearly underpin regulations on parental leave and childcare services (for example Knijn and Kremer, 1997; Leitner, 2003; Ferrarini, 2006; Ciccia and Verloo, 2012). This analysis is, therefore, based on the premise that the two policies determine 'proper' parenthood ideals, that is, they frame the ways in which women engage in employment and men in parenting.

This is where the contribution of this chapter lies. A critical perspective on the power of 'standard' policy measures to explain policy logics is presented and an approach that puts legal formulations on parental leave and childcare services in the centre of analysis is suggested. To capture state assumptions about social organization of care and gender roles, I expanded upon Weber's (1949) use of 'ideal types' and evaluated policies across multiple dimensions. Then, I examined their combinations and classify policies using the 'varieties of familialism' framework. Thus, this chapter follows in four sections. First, the issue of how to think about policies in the area of childcare in terms of social organization of childcare, mothers' employment and active fatherhood is considered. Then, analyses and theoretical models of varieties of familialism are connected, and the differences across countries are mapped. Drawing on these, the analytical potential in eight post-socialist EU countries is investigated. The chapter concludes with critical reflections and directions for future research.

\section{Theoretical perspectives}

Women's access to independent income largely remains structured by widespread gendered parenting and caring, whereby women continue to bear the main responsibilities. Scholarship on female employment and the gendered welfare state research has uniformly found that female employment generally drops subsequent to childbirth and that, in general, mothers of young children are economically more disadvantaged across countries (for example Gupta 
and Smith, 2001). The size of their disadvantage and the proportion of women who withdraw from paid employment after childbirth, however, vary across welfare states.

The welfare states differ in the extent to which they consider the uneven capacity of women to invest in paid employment: whilst most assume that men and women equally need to earn for their own security, not all assume their equal obligations to care for dependants (Pascall and Lewis, 2004: 391). Familialistic welfare states promote and rely on traditional gendered caring, either explicitly (by investing in family care) or implicitly (by withdrawing support to carers), thus imposing different childcare penalties on women, the primary carers, around childbirth. By contrast, de-familialistic welfare states facilitate women's paid employment.

Relative to other scholars, Leitner (2003) argues that each welfare state combines elements of both familialism and de-familialism, and thus reinforces, or challenges gender roles by providing 'incentives to ensure that care provision is shared on equal terms among male and female family members' (Leitner, 2003: 367). She maintains that in the area of family policy, state support of the familial caring function ostensibly reflects in parental leave and childcare services; these are key mechanisms through which the state bolsters the incentives for women's continuous employment and men's active parenting. By providing leave, the state grants parents time off from work to care for a child, secures their labour market position (for example Knijn and Kremer, 1997), and attracts women of childbearing age to enter the paid labour force to qualify for the benefits (for example Rubery et al., 1998: 223-234; Ruhm, 1998). By providing childcare services, the state releases carers to engage in paid employment (Esping-Andersen, 2009: 80; Mandel and Semyonov 2005: 950). Thereby, it shapes women's prospects for gaining income during their working lives and into retirement (Meyer and PfauEffinger, 2006). 
However, I contend that such a seemingly straightforward relationship is somewhat deceptive; using Leitner's (2003) varieties of familialism framework I argue that it is the overall policy design that signals whether or not the state supports women's continuous employment and challenges gender roles and that parental leave and childcare services are two sides of the same coin (Misra et al., 2010); parents view and experience them as a 'package' which shapes their options following childbirth. Therefore, to fully understand their implications, the underlying logics of these policies must be considered, teasing out differences in policy configurations.

\section{Varieties of familialism}

The concept of state de-familialism, which grounds this analysis, has been developed with somewhat different emphases since the mid-1990s (for example Lister 1990; McLaughlin and Glendinning, 1994). Its central idea is that the welfare states differ in 'the degree to which an individual adult can uphold a socially acceptable standard of living, independently of family relationships, either through paid work or through social security provisions' (Lister, 1997: 173).

In the more recent literature, the concept has centred on care policies (Korpi, 2000; Leitner, 2003; see also Saraceno and Keck, 2008). Leitner (2003) provides a 4-type analytical conception of state de-familialism, which teases out critical distinctions between states and encourages us to think about connections across policies. The author maintains that policy conceptual logics reflect how welfare states choose to allocate childcare responsibilities between the state, the family and the market, and within the family between men and women. Thereby, policy combinations are organized in a 4-type framework of state de-familialism, that is, explicit and implicit familialism, de-familialism, and optional de-familialism, which is concerned with the degree to which the welfare states assume and support family 
interdependencies, and reinforce, or challenge, gendered care-giving. Familialism promotes and supports familial childcare. States do this either implicitly, by leaving parents without publicly financed support or explicitly, by rewarding them with public money to provide childcare themselves (that is the 'caregiver parity model' by Fraser, 1994). In contrast, defamilialism promotes the dual-earner family model (that is, the 'adult worker model' by Lewis, 2001: 154), with the state investing in publicly funded childcare, whereas optional defamilialism affords parents to choose between preferable childcare options.

In this analysis, I use Leitner's (2003) conceptualization for the following reasons. First, it distinguishes between policy areas, such as childcare and old age, relative to the broad welfare-state regimes. Second, legal regulations become central analytical dimensions relevant to parents with preschool children. Third, it questions assumptions in which policy components combine to reflect different policy logics; namely, different combinations frame different opportunities or constraints. For example, a too brief or overly long leave both increase the likelihood that mothers, but not the fathers, withdraw from the labour market, particularly those in less protected and secure jobs (for example Esping-Andersen, 2009: 87). Likewise, employers may penalize the (prospective) carers and avoid employing women of childbearing age to avoid any risk of their longer exits (Fagan and Hebson, 2005: 90). Similarly, when the state provides parental leave but no public childcare alternatives, it increases the conflict between women's aspirations to achieve economic independence and their roles as caregivers. Thereby, the two policies can 'threaten to recreate earlier forms of gender inequality in a new form' (Jacobs and Gerson, 2004 in Mandel and Semyonov, 2005: 951). Fourth, egalitarianism is another important element in this concept, as policies can frame the ways in which women and men engage in parenting. Hence, it captures the policy transformative potential, that is, the extent to which the state challenges gender roles. Lastly, it recognizes that de-familialism may occur through both the state and the market. The two 
are, however, assigned different conceptual statuses, acknowledging that recourse to the consumer market is mediated both by the family resources and the alternatives available through parental leave. Such theoretical observations, therefore, give rise to intriguing implications of childcare policies, calling for a systematic analysis of how they are designed. In this endeavour, it offers fruitful lines for analytical developments about the gendered implications of the welfare state in a country-comparative perspective; providing flexible conceptualizations it allows us to also include countries beyond the 'standard' welfare-states regimes.

\section{Methodological considerations}

The study was undertaken in three steps. First, policy programmes on childcare leave and childcare service provision between 2000 and early 2009 were analysed. Then, employment trends between 2002 and 2008, utilizing the employment rates for mothers with pre-school children, relative to other women in the same country were analysed. Finally, whether maternal employment rates vary in tandem with childcare policies was explored. This analysis focused on the period between 2000 and early 2009, in order to avoid changes caused by the recent economic recession. Post-2008 developments are an interesting study case on their own: European societies are facing or preparing to face transitions that will have a major impact on employment, in particular for some groups in the labour force or sectors of the economy. Fiscal shortfalls have undermined efforts to expand the welfare state, and the overall retrenchment has spurred significant cuts in family policy. This, yet another tumultuous period in their short post-socialist history, would, thus, require a separate study.

\section{Country selection}

This chapter covers an eight-country analysis of the policy-employment nexus, comprising the Czech Republic, Estonia, Hungary, Latvia, Lithuania, Poland, Slovakia and Slovenia. 
These were selected because they form a somewhat coherent post-socialist group (von Wahl, 2008: 27). Moreover, they represented different socialist regimes with different roles of the state and influence of organized politics, which alone implies interesting internal diversity. Whilst Slovenia was a constituent republic of Yugoslavia, others formed the Eastern Bloc with the 'Soviet model' of state socialism. Of these, only Estonia, Latvia and Lithuania were constituents of the Soviet Union, whereas the Czech Republic and Slovakia (Czechoslovakia at the time), Poland and Hungary were 'independent' states since 1918 (for example Motiejūnaite, 2008: 19). That notwithstanding, the Soviet Union had much political and economic influence and control over these countries (for example Fuchs and Klingemann, 2002: 28). Furthermore, they are similar in terms of their progress in democratization, and had similarly advanced labour market structures (that is employment opportunities) before 2009 . Lastly, other post-socialist countries lag behind the 'catching up' with Western Europe (for example von Wahl , 2008: 27; Domsch et al., 2003: 11), whilst East Germany lost its state when it reunified with West Germany; hence, they are omitted from this analysis.

\section{Policy analysis}

Parental leave and childcare services are 'complex objects of investigation' (Ciccia and Verloo, 2012: 507). They are made up of a multiplicity of relevant components; these include the duration and payment of leave, flexibility, eligibility, accessibility, affordability, and quality of services, and each carries implications for the policy as a whole (Leitner, 2003; Javornik, 2010). This study assessed multiple policy components as structural elements that can combine into a 'package' that is available to working parents following childbirth. Considering their impact on gender roles and parental employment it offers a new typology for understanding the policy-employment nexus. 
This analysis builds on my earlier work (Javornik, 2012; 2014b), in which I used Weber's ideal types and developed an index of de-familialism, which measures the degree to which the state supports women's continuous employment and promotes active fatherhood. Its central concerns are related to the extent to which the states: (a) support public childcare, (b) financially compensate family care, and (c) expect women and men to engage in childcare.

My analysis is based on the premise that policies are conceptually rooted, and that their underlying logics can be best understood through legal documents; through laws, the state regulates who should be the primary caregiver and who should bear the costs of childcare. To assess parents' opportunities and constraints, I focus on working parents with preschool children because of the volume of their childcare responsibilities. This builds on the assumption that stages in people's lifecycles are causally linked; the choice of motherhood is a key element in family decision-making due to the costs associated with employment interruptions (for example Esping-Andersen, 2009: 24). The policies I consider are for children from birth until the mandatory school age: younger children demand more attention and time compared with older children who are more independent. Moreover, older children are obliged to go to school; hence, access to school is granted without delay, and childcare needs subside (for example Gornick et al., 1997: 54-5; Gilbert, 2008: 6).

In this analysis, policies on parental leave and childcare services are analysed as a single policy programme related to childcare. These are distinct from other work-family measures in two ways. First, they frame parents' opportunities and constraints following childbirth. With reference to empirical studies of female employment, they critically frame women's return to employment following childbirth, whereas other work-family policy measures (for example working time, workplace flexibility) frame the ways in which women return to work and parents combine multiple roles. Second, they reflect cultural scripts for socially acceptable 
allocations of childcare, and hence for 'proper' parenting. Central analytical categories are legal formulations on parental leave and childcare services. These provide the right to time off from work for parental care, cash for family care and the right to external childcare. I evaluate them across 11 attributes from which assumptions about their implications can be drawn; these are examined as single objects of inquiry, and then through their combinations (the methodology is described in detail in Javornik, 2012 and 2014b).

I draw the de-familialistic marker between parental leave (familialism) and childcare services for children aged from birth to school age (de-familialism). Policies on leave - maternity, paternity, parental, and extended childcare leave - support family care while allowing parents to stay connected to employment (Misra et al., 2010). Maternity, paternity and parental leaves are childbirth-related and accompanied by earnings-related benefits, whereas extended childcare leave refers to a longer leave which is either paid or not, and is available to wider groups of parents. Henceforth, I use 'parental leave' to refer to all these types. When more than one type is granted, I followed the rule of the most 'familialistic' option and consider the longest period available. Given that in some countries differential arrangements are possible, such as in the case of multiple births or the birth of a sick child, I followed Smith and Williams (2007) and considered the least generous regulation.

Policy on leave is analysed through six components (Table 10.1). Limited theoretical knowledge about the implications of some components prevented me from considering certain legal aspects, such as eligibility according to parents' employment histories, or benefit payment caps (the ceilings); since there is no standard way to determine what is optimal, erroneous conclusions could be drawn (Bradshaw et al., 2007; Plantenga et al., 2009: 25). Exclusion of these regulations is, however, acceptable (Smith and Williams, 2007; Ciccia and 
Verloo, 2012), considering that the focus here is on norms and not on actual outcomes of policy regulations.

Childcare services support the early education of children and help parents to combine family with employment (for example Misra et al., 2010). I included regulations on publicly funded services for children aged from birth to the compulsory school age in centre-based day care, and focused on five aspects that pertain to the availability, affordability, quality and intracountry disparity in service provision. When municipalities are responsible for childcare services, I checked whether national regulations ensure that these are comparable across the state.

Each policy component was assessed and scored against a set of theoretically-guided standards, with scores ranging between 1 and 8 (see Table 10.1; for a full list of assumptions and methodology see Javornik, 2012 and 2014b): the higher the score the closer the component to the optimal arrangement and the higher its transformative potential (that is the state support for female employment and active fatherhood). There is no simple formula to determine the optimal regulation in a country, and the preferences, social norms and workplace cultures may shape what is considered optimal. In this study, assessment criteria were sourced from the predominant theories and empirical evidence on female employment and gender equity. This approach is based on endorsing maternal employment and active fatherhood and I considered the optimal policy type to be 'supported de-familialism'. This is characterized by gender-neutral, well-paid and flexible parental leave, with incentives for active fatherhood. After one year, publicly financed childcare becomes a pronounced alternative to family childcare. The state accommodates the childcare needs of as many parents as possible by prescribing accessible, affordable, and high-quality public services across the state. 
I hypothesise that such policy provision generates incentives for women's continuous employment, and positively correlates with employment rates for women with pre-school children. Other policy models generate incentives for women to retreat from the labour force for a longer period of time after childbirth, and do not challenge gender roles. On the one hand, when the state subsidizes family care, but provides no public childcare options for the youngest children, women are locked into familial care, and the mothers are likely to curtail employment after childbirth. On the other hand, when the state withdraws any public support for mothers in employment, and does not subsidize familial care or public childcare, the same may ensue, because the state assumes, and relies on the family as the primary carer. However, when public policies give parents the choice of using formal childcare or to opt in for familial care, maternal employment will either be low or high, because other factors will drive their labour force participation.

\section{Table 10.1 about here}

\section{Data source}

To ascertain the extent to which national governments consider the uneven capacity of mothers to invest in employment and childcare, I combined and contrasted various sources of information: the Mutual Information System on Social Protection (MISSOC) in EU, Eurydice, the OECD Education at a Glance, and Family Database, the Council of Europe, UNICEF, and national administrative data and data from relevant national agencies and ministries. I also contacted national experts and agencies, who reviewed policy information.

\section{Maternal employment}


Maternal employment ${ }^{1}$ was analysed using two indicators: the employment rates for women with pre-school children, and the employment gaps between women with pre-school children and those without children of that age. Maternal employment rates are defined as employment-population ratios for women with children under seven years of age. The employment gap is a relative measure of the effect of having a pre-school child on women's employment, and measures the difference between the employment rates for women with preschool children, relative to other women in the same country (that is women who either have older children or no children at all).

I focused on women aged between 25 and 49 years, that is, in the age range when women are most pressed with childcare obligations (for example Lewis, 2010: 32; Rubery et al., 1998: 49; EC, 2008a). Furthermore, these countries displayed comparatively lower employment rates for women above 50 years than other EU states (EC 2008a). The selected age group thus allowed the analysis of employment rates for women who had completed their formal schooling but are young enough to rule out a substantial outflow from employment into retirement (for example Antecol, 2003: 4; Scharle, 2007: 167). A woman is considered an employed mother with a pre-school child only if she is that child's mother; however, no differentiation between biological or adoptive is made. This significantly differentiates this study from the published Eurostat's datasets, in which each employed woman who lived in a household with a child was treated as a mother of that child, regardless of whether or not she was their mother (Eurostat, 2008: personal correspondence). Generally, compulsory schooling begins at six years of age. However, there is some cross-country variation in the compulsory pre-primary schooling age: either children have access to or are obliged to enter reception classes or universal schooling between the ages of five and seven. To reach a reasonable level

\footnotetext{
${ }^{1}$ I also analysed the employment rates for men who had pre-school children and those who did not. The employment rates significantly increased for men with pre-schoolers, without any significant cross-country variation during the studied period.
} 
of comparability, I filtered employment data for children from birth to under seven years of age.

To calculate employment ratios (ER), the following formulae were used:

ER women with pre - schoolers $($ in $\%)=\frac{\text { No. of women with children } 0-6 \text {, in employment }}{\text { Total population of women with children } 0-6}$

ER women without pre - schoolers $($ in $\%)=\frac{\text { No. of women without children } 0-6 \text {, in employment }}{\text { Total population of women without children } 0-6}$

In this study, the employment gap between two groups of women is a relative but standardized measure of the intra-country differences in employment rates for women with preschool children and those without. To compute it, I adapted the method used by Gornick and Meyers (2003), and have applied the same mathematical procedure across the countries and over time. Comparing intra-country differences rather than the maternal employment rates allowed the estimation of how the presence of a child affects female employment, as it isolates the effect of having a pre-school child on women's employment (Gornick and Meyers, 2003: 260).

For this analysis, I used Eurostat's tailored extracts of annual Labour Force Survey (LFS) data from the LFS 2000-2012; data for 2000 and 2001 were subsequently dropped because they were incomplete for most countries. The data was analysed for the whole group of women aged between 25 and 49 years; the data was also divided up into age groups (25-29, 30-34, 35-39, 40-45, and 45-49 years), but some groups of mothers were too small, and hence that data is not reported here. To explore women's employment in different stages in family lifecycles, the women were divided into two groups by age of children: those with infants and toddlers ( $0-2$ years) and those with children of play age (3-5 years). The data for mothers with 
older children was also analysed, but no significant variation was found across the eight countries. The data was analysed using SPSS statistical software (version 15; SPSS 2009); it was nested in eight country-level units and the unit of observation was the country.

\section{Varieties of familialism - Graphical analysis}

To provide a synoptic overview of policies, spider charts are used (for example Schütz et al., 1998; Plantenga and Hansen, 1999). Each represents a single country and comprises of 11 equiangular spokes, one for each policy component. Their length is proportional to the score, and ranged between 1 and 8: the higher the score the closer to the optimum. The line connects them into a radial figure that gives each policy a spider web appearance: the larger the area the more optimal the policy: the right-hand side illustrates leave regulations, with childcare services on the left, and the overview reflects their overall configuration.

\section{Figure 10.1 about here}

Figure 10.1 shows how very diversified national policies were between 2000 and early 2009 , with only Slovenia and Lithuania resembling spiders' webs. In the other six countries, family childcare was well entrenched with policies cast in traditionally gendered roles. These six countries largely granted leave as a family entitlement, with limited flexibility in uptake and paternity quota. However, they significantly differed in the monetary value of familial care: whilst Hungary, Estonia, and Czech Republic financially invested in familial care, Poland and Slovakia did not. Maternity leave was too short in Poland and poorly paid in Slovakia. Their parental and extended leaves were means-tested, whereas Slovakia and Hungary did not guarantee the full set of rights for workers returning from leave. In contrast, the Slovenian, Lithuanian, and Latvian leave regulations carried a higher transformative potential. Their oneyear long leaves were open to both parents and paid at a 100 per cent income-replacement 
rate. Slovenia and Lithuania allowed some flexibility in uptake and used the force of paternal quotas: Lithuania granted one month fully-paid paternity leave, and Slovenia combined a 15day leave at 100 per cent pay with 75 days (for which only minimum social insurance was paid by the state) that lasted until the child's third birthday. However, Slovenian leave was cast in terms of female employment - compared to the Lithuanian - and extended full-time family childcare was not supported.

Countries also varied with respect to childcare services, but most distinctly in services for children from birth to three years old. These were the legal responsibility of municipalities in all cases; however, in Slovenia and Lithuania, they were centrally regulated, coordinated, and supervised. Their crèches were available to children from one to three years old and were part of unitary childcare centres. Their regulations reflected a strong emphasis on high-quality services across the state: they were available on a full-time basis throughout the year with some flexibility in provision and a centrally regulated sliding-fee scale. In the other six countries, public childcare for children from birth to three years old was limited and varied across the state, with a strong urban to rural divide. This divide also applied to services for older children; however, Hungary and Poland stood out for legally providing free childcare without any age-limits. Notwithstanding that, they gave the providers permission to set access criteria and charge for any extracurricular activities, thus hindering access to publicly funded childcare.

To compare these policies with Leitner's (2003) ideal types, I used spider charts. From those, familialism appears to be particularly strong in Hungary, the Czech Republic, and Estonia. Parents in these countries relied upon, and the state supported familial childcare for up to three years; access to longer paid parental leave was a key feature of this type, whilst public childcare services were limited. Following Leitner (2003), these are characteristics of explicit 
familialism, since the states equate the right to family childcare with the family's obligation to provide it. This is reflected in the wide gaps in the employment rates for women with preschoolers compared to those without, with a range of up to 50 percentage points in the Czech Republic and Hungary (Figure 10.2 below).

In contrast, Poland, Slovakia and Latvia leave parents practically without any public support. This resembles implicit familialism. Whilst such regulations do not explicitly promote traditional gender roles, the lack of public support implicitly puts the responsibility for childcare primarily within families. Latvia, however, stood out with a high score on parental leave. Whilst its leave policy is closer to the optimal, the state does not provide public alternatives after one year. Given a high reliance on private childcare and limited regulation in the consumer markets, access to high-quality childcare services was limited in all three countries, particularly for low-income families. I also found a negative association between the employment of women with pre-schoolers and women's education (not reported herein) given that education is related to one's potential wage (for example Steiber and Haas, 2009: 646).

Slovenia and Lithuania focus on women's continuous employment, which is reflected in the policy logic of supported defamilialism. Parental leave generates incentives for the continuous employment of mothers and a more active fatherhood following childbirth, and leave and childcare services are contiguous. In Slovenia, public responsibility for childcare has been a long-standing principle and parents' rights to family time have received limited recognition: whilst it remains a cultural norm to spend a year with the new born baby, parents have been incentivized to use public childcare thereafter (Javornik, 2014a). This reflects in their maternal employment rates, which are the highest in the EU and the OECD: the gaps between different groups of women are narrow, and mothers prevailingly work on a full-time basis. 
Optional de-familialism remains as an ideal; none of the analysed countries equally distributes childcare responsibilities between the state and the family, and between the mother and the father. The Lithuanian, Hungarian and Estonian policies came close. In 2008, they provided extended paid leave as well as limited crèches for the youngest. Then again, their leave was cast in traditional gender roles, paid at a reduced rate and granted as a family right. Furthermore, frequent changes to this programme during the 2000s suggest that, in practice, their governments are compensating for limited public childcare services, given that family childcare costs less than setting up and maintaining crèches. In summary, a cultural script that phases out the gendered roles of a father and a mother and replaces them with the functional roles of a 'parent' does not exist in these countries.

\section{Discussion}

The policy types of the eight countries share core characteristics with Esping-Andersen's (1990), Korpi's (2000), and Fraser's (1994) typologies. First, Slovenian and Lithuanian supported de-familialism could be compared with the social democratic ideas of the Nordic states. These grant gender-neutral leave, promote active fatherhood, and view childcare as a social responsibility. Thereby, they first support 'the universal breadwinner' (Fraser, 1994), followed by the 'dual-earner/public-carer' model (Korpi, 2000: 144). Second, Hungarian, Czech and Estonian explicit familialism resembles the socially conservative principles of Korpi’s (2000) 'single-earner' or Fraser's (1994) 'caregiver parity’ model. Their policies are shaped by the subsidiarity principle, which stresses the primacy of financially supported family childcare. Third, implicit familialism in Poland, Slovakia, and Latvia resembles a liberal type, where social benefits are largely organized to preserve the commercial markets. Although their policies are not explicitly cast in gendered terms, they nonetheless have gendered and class implications. 
In the post-2008 period, however, state interventions in familialism rather than in public childcare have become a prominent mechanism supported by many national governments. In Estonia, a slow accumulation of moderate extensions of leave could thus strengthen its currently weak conformity to explicit familialism. Unless the Lithuanian state increases the investments in public services for the youngest, it too may shift towards explicit familialism. Moreover, heated discussions are going on between those advocating that a larger part of the parental insurance should be individualized (that is more daddy weeks) and those arguing that such decisions should be made in the family (currently in, for example the Czech Republic, Poland and Slovenia).

Policy change is part of 'normal policymaking' (Hall, 1993: 278-80), but a key question is whether the policies undergo a fundamental reshaping. Therefore, it remains to be explored whether the post-socialist countries are reaffirming their post-socialist status or are, instead, transforming their post-socialist characters. Although preliminary, this analysis offers some perspectives for further research that could derive more generalizations about policy stability and change in the post-socialist world.

\section{Maternal employment and the employment gaps}

Employment statistics confirm a paradoxical panorama and show wide cross-country variation. To find out how the employment and policy profiles correspond with each other, I used a simple analytical approach - countries were coloured according to their policy clusters: the green lines illustrate countries with the supportive de-familialistic policy model, the blue the implicitly familialistic policy group and the red the explicitly familialistic group. The means are used as measures of central tendency, to show whether the values are high (above the mean) or low (below). 


\section{Figure 10.2 about here}

Discernible overall trends can be seen: the gaps were the widest in the Czech Republic and Hungary with the explicitly familialistic policy model (red lines), and Slovakia with the implicitly familialistic policy model (blue dotted line). The Estonian employment gaps were also above the mean value for the eight countries (weaker membership in the explicitly familialistic group). The Slovenian and Lithuanian trends are opposite (green lines). In fact, Slovenia was the only country in which maternal employment rates were higher than for other women; their employment gaps oscillated between -5.1 and +0.3 percentage points during the analysed period. In Latvia and Poland (implicit familialism) employment gaps were below the mean value. However, I did find wider employment gaps in women aged 25-34 years, compared to women aged 25-49 years, with significant variation over the period under review: the gaps for women aged 25-29 years increased by about ten percentage points over a period of six years (the two had similar values at the beginning and at the end of the period under review), and for women aged 30-34 years by about 20 percentage points.

The employment gaps largely corresponded to policy changes, and generally widened as governments either extended leave or installed more generous leave payments (for example in the Czech Republic, Estonia and Lithuania). This includes the three countries with the implicitly familialistic policy model - their governments slightly increased the amounts of flat-rate leave payments over the period under review, and Latvia also extended universal access to formal day care to all children up to five years of age, in order to address low service provision. Employment trends were fairly stable over time in most countries, except the Baltic States, especially Latvia, where maternal employment rates fluctuated significantly over the reviewed period. 
Furthermore, a significant variation exists in mothers' employment rates by age of children: these were the lowest for women with children under the age of three, followed by women with older pre-school children. Figure 10.3 illustrates the widest gaps between mothers with the under-3s and older pre-school children in countries with the explicitly familialistic policy model (Estonia, the Czech Republic and Hungary) and Slovakia with the implicitly familialistic policy model, and the narrowest in Slovenia and Lithuania with the supported defamilialistic policies. The differences between countries get smaller, and maternal employment increases with children's age.

\section{Figure 10.3 about here}

The most significant drop was in the employment rates for mothers with lower levels of education - especially in Hungary and the Czech Republic, where the states subsidize familial childcare over a longer period of time, and they were the lowest in Slovakia, where parents do not have any public alternatives. By contrast, mothers with higher levels of education return to employment in the greatest number as their opportunity costs of staying at home are the highest.

\section{Figure 10.4 about here}

These findings complement the micro-economic rationality thesis: childcare benefits increase the disposable income of parents and the income from cash benefits takes the financial pressure to stay in low-paid employment off women. Because affordable public childcare options are limited, a family would make too few financial gains from women's employment. Alternatively, more highly educated women have more economic resources to shop around 
for different forms of care: from child minders providing services in the unregulated service market to the limited commercial service markets or care provided by informal networks.

However, how can the higher employment rates of mothers in Poland and Latvia be explained, the two countries with implicitly familialistic models where the state leaves the vast majority of working parents almost without support? With reference to the extensive literature on the factors of female employment (for an overview see Javornik, 2010), it could be assumed that the educational attainment of mothers, the income needs of households, the size of the public service and the agricultural sectors (both proxies for employment opportunities for women), carry some explanatory potential in this country group. Namely, more highly educated women in these countries found employment in the public service sectors, which offered more secure jobs and better working environments (Javornik, 2010). Hence, they had more incentive to stay active in the period of active motherhood.

Considering the choice that higher educational attainment brings, why did we also see higher employment rates for mothers with lower levels of education - on average they have more traditional attitudes as well as lower incomes to purchase commercial day care services? The higher income needs of households provide a plausible explanation. Given that their household income is on average lower, and that the states provide no, or little, family cash benefits, women's wages increase disposable income, and help to uphold the living standards of their households. In Poland and Latvia, these mothers still seem to find jobs in the agricultural sector and low-paid service sector, where the demand for women with lower levels of education is higher (Javornik, 2010).

However, who cares for their children? In my previous work (Javornik, 2010; 2014) I found that the informal childcare markets have had a long tradition in these countries - be it by the 
informal network or by the (generally untrained) childminders in the semi-formal service markets. Informal childcare has been highest in Poland and the Baltic States, owing to a growing proportion of unemployed and low-waged women. These women offered childcare, largely to uphold the living standards of their own households. In sum, the widespread unregulated service markets and day care by informal networks (either paid or unpaid) provide options for those mothers to engage in paid employment, while at the same time take the pressure off the national governments to address the issue of low state support in terms of cash for either care or public childcare services.

\section{Concluding remarks}

The main research question of this chapter was whether policies on leave and childcare services accounted for the shape of the employment of mothers in eight post-socialist countries. Drawing upon detailed policy characteristics I found compelling cross-country variation, showing that different combinations of policies that support family care-giving, and those that de-familialize it, led to significantly different outcomes in terms of mothers' employment.

One unambiguous finding was that varieties of familialism exist among the countries that have too often been treated as representing a homogenous welfare-state regime. By turning attention to parental leave and childcare services, I found that Slovenia and Lithuania pragmatically shifted social investments from familial to public childcare in order to facilitate women's continuous employment, and this was reflected in the narrowest employment gaps between women with pre-schoolers and those without. Belonging to the supported defamilialism cluster, they first explicitly invested in familialism through cash for care, whilst simultaneously promoting active fatherhood through fully compensated parental and paternity leaves. After a year, publicly financed childcare becomes a pronounced and financially 
supported alternative (that is de-familialism). By contrast, explicit familialism in Hungary, the Czech Republic and Estonia financially supported familial childcare. Familial childcare was not only supported, but also expected for up to three years, while also reinforcing gendered parenting and this was clearly reflected in their widest employment gaps. Lastly, implicit familialism in Poland, Slovakia and Latvia leaves parents without public support. Their mixed employment gaps suggest, however, that the mothers in these countries seek/obtain childcare in the unregulated and regulated service markets.

Drawing upon maternal employment data, I found evidence in favour of the childcare policies' explanation. In countries with gender-neutral leave of moderate duration, followed by affordable, adequate and accessible formal childcare services, the employment rates for mothers with pre-school children were significantly higher. Whilst these are important preconditions for women to enter the labour market and to more efficiently manage their work and family demands, such policy designs seem especially important for the employment of low-skilled and low-income mothers. These women are often employed in less protected and less secured jobs, with lower levels of social protection (similar finding by Del Boca et al., 2009). This chapter has shown that these mothers have the lowest employment rates in countries where childcare options are limited, and the correlation between their employment and childcare policies was also stronger (not reported herein; see Javornik, 2010).

These findings suggest two things. First, these policies are a precondition for mothers' employment, and have broader social implications upon women's economic and social autonomy. The findings underpin the importance of well-paid leave of moderate duration and adequate, affordable and accessible high-quality formal childcare services for enhancing women's continuous employment. Any other type of childcare provision depresses their employment, and reinforces the conventional gender division of labour. Second, they 
complemented the micro-economic rationality thesis that women make a rational consumption choice between their potential market income and the value of time spent outside paid work. A low income family with childcare needs would make too few financial gains from a woman's labour force participation when affordable formal childcare options are limited. By contrast, mothers with higher levels of education returned to the labour markets in the greatest numbers, because their opportunity costs of staying at home are higher. They largely found employment in the public service sector, which offers more secure jobs and better working environments. Moreover, they also have more economic resources, and can shop around for different forms of care: baby sitters who provide services in the unregulated service market, they can purchase expensive childcare services in the limited commercial service markets, or rely on care by other members of their families. This indicates that educational attainment and the income needs of households suppress rather than rival the childcare policies' explanation, and that the unregulated service markets and childcare by informal networks provide options for mothers' employment in countries with limited state intervention. This suggests that many issues raised in this chapter are also relevant to social and employment policies more broadly. Lastly, this analysis highlighted that the total female employment rates misrepresent the employment behaviour of different groups of women, and thus mask large variations between women within the same country, as well as between countries. The considerable variations in the employment rates for different groups of women, thus, demonstrate that we are likely to misinterpret maternal employment by only examining total female employment.

In summary, the proposed approach to examining policies, maternal employment and their interrelationship allows researchers to test new hypotheses; it also has the potential to discredit the claims of post-socialist exceptionalism, given that mothers with small children across industrialized countries essentially face the same challenges in managing often 
competing demands. However, given that its focus was on policies tailored to dual-earner heterosexual couples, future research should incorporate differential statutory entitlements for different groups of parents. Against this background, these findings should be read as theoretically informed hypotheses that raise issues for further research. 
Antecol, H. (2003) 'Why is there Cross-Country Variation in Female Labour Force Participation Rates? The Role of Male Attitudes Toward Family and Sex Roles', Claremont Colleges Working Papers in Economics (Claremont McKenna College), available at: http://opus.zbw-kiel.de/volltexte/2005/2686/.

Bradshaw, J., Hoelscher, P. and Richardson, D. (2007) 'Comparing Child Well-Being in OECD Countries: Concepts and Methods', Innocenti Working Paper, 2006-03 (Florence: UNICEF Innocenti Research Centre).

Ciccia, R. and Verloo, M. (2012) 'Parental leave regulations and the persistence of the male breadwinner model: Using fuzzy-set ideal type analysis to assess gender equality in an enlarged Europe', Journal of European Social Policy, 22 (5), 507-28.

Datta Gupta, N. and Smith, N. (2001) 'Children and Career Interruptions: The Family Gap in Denmark', IZA Discussion Paper, No. 263 (Bonn: ZA).

Del Boca, D., Pasqua, S. and Pronzato, C. (2009) 'Motherhood and market work decisions in institutional context: a European Perspective', Oxford Economic Papers, 61 (1), i147i171.

Domsch, M. E., Ladwig, D. H. and Tenten, E. (2003) Gender Equality in Central and Eastern European Countries, Forum Personalmanagement (Frankfurt am Main, Berlin, Bern, Bruxelles, New York, Oxford, Wien: PETER LANG Europäischer Verlag der Wissenschaften). 
EC (2008) 'Indicators for monitoring the Employment Guidelines including indicators for additional employment analysis', 2008 compendium (Brussels: European Commission, DG Employment, Social Affairs and Equal Opportunities, Unit D-2).

EC (2008a) 'Demography Report 2008: Meeting Social Needs in an Ageing Society', Commission staff working document (Brussels: European Commission).

Einhorn, B. (1993) Cinderella Goes to Market: Citizenship, Gender and Women's Movements in East Central Europe (London and New York: Verso).

Eliason, S. R., Stryker, R. and Tranby, E. (2008) 'The Welfare State, Family Policies and Women's Labor Force Participation: Combining Fuzzy-Set and Statistical Methods to Assess Causal Relations and Estimate Causal Effects' in L. Kenworthy and A. Hicks (eds) Method and Substance in Comparative Political Economy (Basingstoke: Palgrave MacMillan).

Esping-Andersen, G. (1990) The three worlds of welfare capitalism (Cambridge: Polity Press).

Esping-Andersen, G. (2009) The incomplete revolution. Adapting to women's new roles (Cambridge and Malden: Polity Press).

Eurostat (2008) 'Reduced gap in employment rates between men and women in the EU27', Eurostat News Release, 158/2008 (Luxembourg: European Commission).

Fagan, C. and Hebson, G. (2005) Making work pay' debates from a gender perspective. A 
comparative review of some recent policy reforms in thirty European countries (Brussels: European Commission).

Ferrarini, T. (2006) Families, States and Labour Markets: Institutions, Causes and Consequences of Family Policy in Post-War Welfare States (Cheltenham: Edward Elgar Publishing).

Fodor, E., Glass, C., Kawachi, J. and Popescu, L. (2002) 'Family policies and gender in Hungary, Poland, and Romania', Communist and Post-Communist Studies, 35, 47590.

Fraser, N. (1994) 'After the Family Wage. Gender Equity and the Welfare State', Political Theory, 22 (4), 591-618.

Fuchs, D. and Klingemann, H.-D. (2002) 'Eastward Enlargement of the European Union and the Identity of Europe', West European Politics, 25 (2), 19-54.

Funk, N. (1993) 'Introduction: women and post-communism' in N. Funk and M. Mueller (eds) Gender politics and post-communism: reflections from Eastern Europe and the former Soviet Union (New York: Routledge), pp. 1-14.

Gal, S. and Kligman, G. (2000) The Politics of Gender after Socialism (Princeton, New Jersey: Princeton University Press).

Gilbert, N. (2008) A Mother's Work. How Feminism, the Market, and Policy Shape Family Life (New Haven and London: Yale University Press). 
Gornick, C. J. and Meyers, K. M. (2003) Families that work. Policies for Reconciling Parenthood and Employment (New York: Russell Sage Foundation).

Gornick, J. C., Meyers, M. K. and Ross, K. E. (1997) 'Supporting the Employment of Mothers: Policy Variation Across Fourteen Welfare States' Working Paper No. 139 (Luxembourg: LIS)

Hall, P. (1993) 'Policy Paradigms, Social Learning, and the State: The Case of Economic Policymaking in Britain', Comparative Politics, 25 (3), 275-96.

Hantrais, L. (2004) Family Policy Matters. Responding to family change in Europe (Bristol: Policy Press).

Javornik, J. (2010) Exploring Maternal Employment in Post-Socialist Countries: Understanding the Implications of Childcare Policies, $\mathrm{PhD}$ Thesis (Southampton: University of Southampton).

Javornik, J. (2012) 'Rethinking comparative childcare policy analysis. Example of Central and Eastern Europe', Welfare Studies Working Paper Series, 10/2012 (Department of Sociology: Umeå University), available at: http://www.soc.umu.se/digitalAssets/103/103911_10_2012_javornik.pdf, date accessed 13 November 2013.

Javornik, J. (2014a) 'L'adieu au modèle de l'homme soutien de famille. Le présent postsocialiste à la lumière du passé socialiste', Politiques sociales et familiales, Dossier 
Genre, famille et Etat en Europe centrale et orientale, 115, 11-24, available at: http://www.caf.fr/sites/default/files/cnaf/Documents/Dser/PSF/115/PSF115_1_JanaJav ornik.pdf, date accessed 8 April 2014.

Javornik, J. (2014b) 'How to measure state de-familialism: Contesting post-socialist exceptionalism', Journal of European Social Policy, 24 (3), 240-257.

King, L. (2002) 'Postcommunist Divergence: A Comparative Analysis of the Transition to Capitalism in Poland and Russia', Studies in Comparative International Development, $37(3), 3-34$

Knijn, T. and Kremer, M. (1997) 'Gender and the Caring Dimension of Welfare States: Toward Inclusive Citizenship', Social Politics, 4 (3), 328-61.

Korpi, W. (2000) 'Faces of Inequality: Gender, Class, and Patterns of Inequalities in Different Types of Welfare States', Social Politics, 7 (2), 127-91.

Kovács, J. M. (2002) 'Approaching the EU and Reaching the US? Rival Narratives on Transforming Welfare Regimes in East-Central Europe', West European Politics, 25 (2), $175-204$.

Leitner, S. (2003) 'Varieties of Familialism. The caring function of the family in comparative perspective', European Societies, 5 (4), 353-75.

Lewis, J. (2010) Work-family balance, gender and policy (Cheltenham, UK and Northampton, USA: Edward Elgar). 
Lewis, J. (2001) 'The Decline of the Male Breadwinner Model: Implications for Work and Care', Social Politics, 8 (2), 152-69.

Lister, R. (1990) 'Women, Economic Dependency, and Citizenship', Journal of Social Policy, $19(4), 445-67$.

Lister, R. (1997) Citizenship: Feminist Perspectives (New York: New York University Press).

Mandel, H. and Semyonov, M. (2005) 'Family Policies, Wage Structures, and Gender Gaps: Sources of Earnings Inequality in 20 Countries', American Sociological Review, 70 (6), 949-67.

McLaughlin, E. and Glendinning, C. (1994) 'Paying for Care in Europe: Is There a Feminist Approach?', in L. Hantrais and S. Mangen Family Policy and the Welfare of Women (University of Loughborough: Cross National Research Papers), pp. 52-69.

Meyer, T. and Pfau-Effinger, B. (2006) 'Gender Arrangements and Pension Systems in Britain and Germany: Tracing change over five decades', International Journal of Ageing and Later Life, 1 (2), 67-110.

Misra, J., Budig, M. and Böckmann, I. (2010) 'Work-Family Policies and the Effects of Children on Women's Employment and Earnings', LIS Working Paper Series, 543 (Luxembourg: LIS).

Motiejūnaite, A. (2008) 'Female employment, gender roles, and attitudes. The Baltic 
countries in a broader context', Doctoral Thesis, Stockholm Studies in Sociology, New Series, 29, 35-53.

Pascall, G. and Lewis, J. (2004) 'Emerging Gender Regimes and Policies for Gender Equality in a Wider Europe', Journal of Social Policy, 33 (3), 373-94.

Pascall, G. and Manning, N. (2000) 'Gender and social policy: comparing welfare states in Central and Eastern Europe and the former Soviet Union', Journal of European Social Policy, 10 (3), 240-66.

Pascall, G. and Kwak, A. (2005) Gender Regimes in Transition in Central and Eastern Europe (Bristol: Policy Press).

Pettit, B. and Hook, J. (2005) 'The Structure of Women's Employment in Comparative Perspective', Social Forces, 84 (2), 779-801.

Plantenga, J. and Hansen, J. (1999) 'Assessing Equal Opportunities in the European Union', International Labour Review, 138 (4), 351-79.

Plantenga, J., Remery, C., Figueiredo, H. and Smith, M. (2009) 'Towards a European Union Gender Equality Index', Journal of European Social Policy, 19 (1), 19-33.

Rostgaard, T. (2004) 'Family Support Policy in Central and Eastern Europe - A Decade and a Half of Transition', Early Childhood and Family Policy Series No 8 (Copenhagen: The Danish National Institute of Social Research, UNESCO Education Sector). 
Rubery, J., Smith, M., Fagan, C. and Grimshaw, D. (1998) Women and European Employment (New York, Routledge).

Ruhm, C. J. (1998). 'The Economic Consequences of Parental Leave Mandates: Lessons from Europe', The Quarterly Journal of Economics, 113 (1), 285-317.

Saraceno, S. and Keck, W. (2008) 'The Institutional Framework of Intergenerational Family Obligations in Europe: A Conceptual and Methodological Overview', First WP1 Multilinks Deliverable, available at: http://www.multilinks-project.eu/wpcontent/uploads/2009/04/Report_Saraceno_Keck_Nov081.pdf, date accessed $2^{\text {nd }}$ December 2013.

Saxonberg, S. and Szelewa, D. (2007) 'The Continuing Legacy of the Communist Legacy? The development of family policies in Poland and the Czech Republic', Social Politics. Special Issue: Gender and State in Post-communist Societies, 14 (3), 351-79.

Scharle, A. (2007) 'The Effect of Welfare Provisions on Female Labour Supply in Central and Eastern Europe', Journal of Comparative Policy Analysis, 9 (2), 157-74.

Schütz, H., Speckesser, S. and Schmid, G. (1998) 'Benchmarking Labour Market Performance and Labour Market Policies: Theoretical Foundations and Applications', Discussion Paper FS I 98 - 205 (Berlin: Wissenschaftszentrum Berlin für Sozialforschung).

Smith, J. A. and Williams, R. D. (2007) 'Father-Friendly Legislation and Paternal Time across Western Europe', Journal of Comparative Policy Analysis, 9 (2), 175-92. 
Steiber, N. and Haas, B. (2009) 'Ideals or Compromise? The Attitude-Behaviour Relationship in Mothers' Employment', Socio-Economic Review, 7 (4), 639-68.

Szelewa, D. and Polakowski, M. P. (2008) 'Who cares? Changing patterns of childcare in Central and Eastern Europe', Journal of European Social Policy, 18 (2), 115-31.

Thévenon, O. (2011) 'Family Policies in OECD Countries: A Comparative Analysis', Population and Development Review, 37 (1), 57-87.

Unicef (1999) 'Women in Transition', The Monee Project, CEE/CIS/Baltics. Regional Monitoring Report, 6 (Florence: Unicef).

Uunk, W., Kalmijn, M. and Muffels, R. (2005) 'The Impact of Young Children on Women's Labour Supply: A Reassessment of Institutional Effects in Europe', Acta Sociologica, $48(1), 41-62$.

van der Lippe T. and Fodor E. (1998) 'Changes in gender inequality in six eastern European countries', Acta Sociologica, 41 (2), 131-49.

van der Lippe T. and van Dijk L. (2001) Women's employment in a comparative perspective (New York: Aldine de Gruyter).

von Wahl, A. (2008) "The EU and Enlargement. Conceptualizing Beyond "East" and "West" ' in S. Roth (ed.) Gender Politics in the Expanding European Union. Mobilization, Inclusion, Exclusion (New York, Oxford: Berghahn Books), pp. 19-36. 
Weber, M. (1949) The Methodology of the Social Sciences (New York: Free Press). 